\title{
NVMO-congres 2002: een congres met uitzicht!
}

In november 2002 vond voor de twaalfde keer het jaarlijkse congres van de Nederlandse Vereniging voor Medisch Onderwijs (NVMO) plaats. Nieuw was de locatie. De vertrouwde bosrijke omgeving van Brabant werd verruild voor een plek aan zee: Congrescentrum Zuiderduin in Egmond aan Zee. Het vernieuwde uitzicht, een nieuwe horizon staat voor het thema waar in medisch onderwijs volop over gesproken wordt: de arts van straks. Er is veel beweging in het medisch onderwijs en velen zijn op één of andere wijze betrokken bij de invulling van een medisch opleidingscontinuüm. Tijdens dit congres hebben we samen gekeken naar wat op ons afkomt, samen gediscussieerd over de toekomstige arts, de initiële en de vervolgopleiding en hoe deze twee zo goed mogelijk af te stemmen.

Het congres trok veel belangstellenden. Verheugend is de constatering dat meer en meer artsen uit de dagelijkse praktijk het congres bezoeken. Er waren in totaal 450 deelnemers die samen 120 voordrachten verzorgden. Tien voordrachten vonden plaats op uitnodiging, de overige 110 bijdragen waren eigen initiatieven van deelnemers.

In 2002 vond voor de tweede keer een uitgebreide reviewprocedure plaats. Hierbij wordt ieder abstract door twee reviewers en een lid van de Werkgroep NVMO-congres gelezen en van commentaar voorzien. Commentaar wordt teruggekoppeld, waarna de indiener het abstract kan bijstellen. Op deze wijze wordt gestreefd de kwaliteit van de abstracts en de voordrachten zelf steeds weer te verbeteren.
Inmiddels kent het congres meerdere presentatievormen. Naast de vertrouwde papersessies, bestemd voor het presenteren van een (afgerond) onderzoek, is in 2001 de postersessie geïntroduceerd. Afgerond of nog lopend onderzoek kan op een zeer interactieve wijze gepresenteerd worden, waarbij veel ruimte is voor discussie. Ook het Lagerhuis debat tijdens de zogenaamde 2-2-8 sessie bleek bijzonder succesvol.

Het wetenschappelijk comité van de NVMO heeft dit jaar voor het eerst geadviseerd over de inhoud en de vorm van het congres. Samen met de Werkgroep NVMOcongres heeft na afloop van het congres een evaluatie plaatsgevonden en zijn thema's voor het volgende congres geëxploreerd. Het wetenschappelijk comité bestaat uit Prof. dr. C.P.M. van der Vleuten (voorzitter), Prof. dr. Th. J. Ten Cate, Mw. dr. J. Cohen-Schotanus, Mw. prof. dr. J.P.M. Denekens en Prof. dr. H.J.M. van Rossum. De Werkgroep NVMO-congres 2002 bestond uit Mw. drs. L.C.R.M.G. Fluit (hoofdorganisator), Mw. dr. D.H.J.M. Dolmans, Dr. ir. P.G.M. de Jong, Dr. P. Room, Prof. dr. A. Derese en Mw. M. StermanVleeschdraager.

Het programma in 2002 werd geopend met een lezing van Mw. mr. W. Sorgdrager over de decentrale selectie. Sinds 1999 mogen instellingen voor hoger onderwijs bij studies waarvoor een numerus fixus is ingesteld, een aantal studenten buiten de loting om, volgens zelf op te stellen criteria, toelaten. Ervaringen van enkele medische faculteiten wezen uit dat dit in verhouding veel tijd c.q. geld kost en dat het 
niet eenvoudig is om criteria te formuleren waarop men zou willen selecteren. Een aantal andere opleidingen daarentegen zijn positief en overwegen om decentrale selectie in te voeren, met name opleidingen in de economische en bedrijfskundige sfeer. Dat betekent echter niet dat het onderwerp selectie van de baan is. Selectie heeft in de afgelopen jaren een andere betekenis gekregen en opleidingen dienen meer verantwoordelijkheid te hebben voor de toelating van studenten.

In de tweede hoofdlezing belichtte Prof. dr. J. De Maeseneer de maatschappelijke relevantie van de artsopleiding. Een actieve participatie in het maatschappelijke debat rond de ontwikkelingen in de gezondheidszorg is onontbeerlijk. Om de arts van straks te kunnen opleiden zullen nieuwe aandachtspunten moeten worden ingevuld op het gebied van onder andere management, werken in flexibele netwerken, multiprofessioneel opleiden, samenwerken met 'nieuwe professionals' en een brede maatschappelijke vorming. Al met al geen eenvoudige opdracht.

De tweede dag van het congres begon met een lezing van Mw. prof. dr. B. Meyboom-de Jong over het rapport 'De arts van Straks'. Dit rapport bevat een voorstel voor een nieuw medisch onderwijscontinuüm dat inspeelt op huidige en toekomstige ontwikkelingen in de maatschappij, de gezondheidszorg en de medische beroepsgroepen. Belangrijke aanbevelingen zijn een goede aansluiting tussen de initiële opleiding tot basisarts en de vervolgopleidingen. De onderwijskundige kwaliteit van de vervolgopleidingen moet verbeterd worden. Daarnaast wordt herstructurering voorgesteld met een gemeenschappelijke basisopleiding tot junior specialist.

's Middags sprak Mw. dr. J.A.A.M. van Diemen-Steenvoorde over de plaats die de algemene ziekenhuizen innemen in de toekomst als het gaat om het opleiden van art- sen, zowel in de basis- als vervolgopleiding. Het toenemend aantal studenten vraagt om een toenemend aantal stageplaatsen voor co-assistenten, maar ook voor arts-assistenten. Gepleit wordt voor de ontwikkeling van academische onderwijs- en opleidingsregio's waarin teaching hospitals en stageziekenhuizen een gezamenlijke verantwoording dragen voor onderwijs en opleiding. Het programma werd afgesloten door Prof. dr. C.P.M. van der Vleuten. Hij blikte terug op het congres en schetste op heldere wijze de ontwikkelingen in het medisch onderwijs. Belangrijke voorwaarde voor de verdere professionalisering is dat er meer wetenschappelijk medisch onderwijskundig onderzoek plaatsvindt. Hiervoor is echter wel een goede infrastructuur noodzakelijk.

In het programma van de eerste dag waren ook vijf parallelle lezingen opgenomen. Iedere spreker deed hierbij aanbevelingen voor de vormgeving van (onderdelen van) de opleiding. Prof. dr. O.P. Bleker benadrukte dat bij de vormgeving van de opleiding van de medisch specialist van morgen goed moeten worden nagedacht over de patiënt van morgen, de zorgverlening en de dokter van morgen. Die dokter is vaker een vrouw, krijgt of heeft kinderen, zoekt een nieuwe balans tussen werk en thuis, wil minder diensten doen en vaker parttime werken. Dr. J. van Dalen besprak de resultaten van het door hem uitgevoerde onderzoek naar de effecten van verschillende programmeringen van communicatietrainingen. Het blijkt dat longitudinale programmering een langer durend effect heeft op de communicatie vaardigheden dan geconcentreerde trainingen. Mw. dr. A.M.B. Janssen-Noordman legde in haar voordracht uit dat voor het leren van complexe vaardigheden een authentieke leeromgeving nodig is die zich richt op de integratie van alle aspecten van die complexe vaardigheden. Gepleit wordt 
om bij het vormgeven van onderwijsprogramma's uit te gaan van een hele-taak benadering. Mw. dr. H.M.J. Raghoebar-Krieger heeft onderzocht met behulp van een logboek welke ziektebeelden uit het Raamplan aanwezig zijn in de praktijk en in hoeverre studenten ervaringen opdoen met deze ziektebeelden. Geconcludeerd kon worden dat een co-schap, gelopen op een algemene en een specialistische onderafdeling samen, voldoende is om te voldoen aan de eindtermen. Dr. P.B.A. Smits tot slot heeft onderzocht hoe effectief het onderwijs in de vervolgopleiding voor bedrijfsartsen is. Performance indicatoren blijken hierbij een waardevol instrument. Opvallend was dat deelnemers het probleemgestuurd onderwijs minder waardeerden, maar dat het wel effectiever was in het verbeteren van de performance.

Evenals in 2001 werd ook in 2002 een prijs toegekend aan de beste paper en de beste poster. De prijs voor de beste paper ging naar K. Overeem uit Maastricht. Het betrof een paper over het gebruik van een portfolio om te reflecteren op de doelstellingen van een zorgstage in het eerste jaar geneeskunde. Het bleek dat studenten vooral geneigd zijn te reflecteren in beschrijvende zin. Voor diepergaande reflectie is strakke begeleiding van een docent nodig. De beste poster was van P. van der Harst uit Groningen. In deze poster wordt de ontwikkeling van een instrument beschreven waarmee kan worden nagegaan welke factoren van invloed zijn op de acceptatie van een toets of toetsmethode door studenten.

Het congres en het Tijdschrift voor Medisch Onderwijs (TMO) zijn twee belangrijke activiteiten van de NVMO die vooral bedoeld zijn als platvorm om ervaringen en ideeën met elkaar uit te wisselen en op deze wijze van elkaar te leren. Dit nummer geeft een impressie van het NVMOcongres 2002. Het bevat artikelen van de sprekers met uitzondering van Mw. prof. dr. B. Meyboom-de Jong. Dit artikel en de artikelen van de twee winnaars van de prijzen voor de beste paper en de beste poster zullen in één van de volgende nummers van TMO worden opgenomen. De slotlezing van Prof. dr. C.P.M. van der Vleuten is na te lezen op: www.fdg.unimaas.nl/educ/cees/nvmo.

De bijdragen in dit nummer zijn beoordeeld door de redactie van het TMO en de leden van de Werkgroep NVMO-congres 2002. Omdat de bijdragen in een aantal gevallen een verslag zijn van de voordracht is hier en daar afgeweken van de standaard criteria voor het beoordelen van een artikel. Met dit nummer hopen wij dat congresgangers interessante en eventueel gemiste voordachten nog eens kunnen nalezen. We hopen in 2003 weer een groeiend aantal deelnemers te kunnen verwelkomen, bekende maar ook nieuwe deelnemers die na het lezen van dit nummer geïnteresseerd zijn in dit congres.

In 2003 vindt het NVMO-congres plaats op 20 en 21 november in Congrescentrum Zuiderduin in Egmond aan Zee. De tot Commissie NVMO-congres omgedoopte Werkgroep NVMO-congres hoopt wederom veel abstracts te ontvangen. Voor meer informatie over het congres: e-mail: congres@nvmo.nl of de website van de NVMO: www.nvmo.nl.

De gastredactie van dit nummer van TMO was de Werkgroep NVMO-congres 2002:

- Mw. drs. L.C.R.M.G. Fluit, hoofdorganisator, Universitair Medisch Centrum St. Radboud Nijmegen

- Mw. dr. D.H.J.M. Dolmans, Universiteit Maastricht

- Dr. ir. P.G.M. de Jong, Leids Universitair Medisch Centrum

- Dr. P. Room, Rijksuniversiteit Groningen - Prof. dr. A. Derese, Universiteit Gent

- Mw. M. Sterman-Vleeschdraager,NVMO

Namens de gastredactie, Lia Fluit, hoofdorganisator 